\title{
THE ROLE OF ISLAMIC SOCIAL FINANCE THROUGH ZISWAF AND BMT DURING THE COVID-19 PANDEMIC
}

\author{
Purwanto', Fitri Nurba Sari², Mona Burasukma $^{3}$, Siti Nursolihah4 \\ 1Faculty of Business, President University, Bekasi \\ 2,3,4Faculty of Economics and Business, Padjadjaran University, Bandung \\ \purwanto@president.ac.id ${ }^{1}$
}

Abstract: This research was conducted to explain the role of Islamic social finance through ZISWAF and BMT during the Covid-19 pandemic. This study uses qualitative methods that use library research techniques. The results of the study indicate that Islamic social finance plays an important role in dealing with declining economic conditions during the Covid-19 pandemic. The existence of ZISWAF can reduce the problem of poverty due to the Covid-19 pandemic, as well as the existence of BMT which can encourage businesses that lack capital and of course can help the government in dealing with existing problems. The role of Islamic social finance is shown by offering solutions to overcome economic problems, namely: the distribution of BLT originating from zakat collection units or from people with more income, assistance in the form of zakat, infaq, or alms; increasing waqf with cash waqf schemes, productive waqf or waqf linked sukuk waqf in order to strengthen waqf; assistance in the form of business capital to Micro, Small and Medium Enterprises (UMKM) groups experiencing crisis conditions; providing venture capital followed by a qardhul hasan loan scheme; providing understanding to increase literacy related to sharia economics and finance; sharia financial technology development. The implication is to help the welfare of the poor so that they become more capable people by providing business capital.

Keywords: Islamic social finance, ZISWAF, BMT, Covid-19

\section{INTRODUCTION}

Corona virus infection is called COVID-19 (Corona Virus Disease 2019) and was first discovered in the city of Wuhan, China at the end of December 2019. This virus spreads very quickly and has spread to almost all countries, including Indonesia, in just a few months. This has made several countries implement policies to impose lockdowns in order to prevent the spread of the Corona virus. In Indonesia itself, the government implements the policy of Enforcing Community Activity Restrictions (PPKM) to suppress the spread of this virus

The Corona virus is a virus that if ignored will have bad consequences, it can even lead to the loss of a person's life. This proves how fierce this disease is, and not just a common influenza disease. At that time, when this virus was very serious, it continued to attack the health of the population in China and even killed many, China felt completely overwhelmed by this disease. Until in the end, the Chinese government implemented a lockdown policy, which obliged everyone to stay indoors with the aim of reducing the number of victims affected by the Covid-19 virus. With the implementation of this lockdown policy, it will indirectly have an impact on the economy. This occurs as a result of decreased activity of the population outside the home, because all resident activities must be carried out in the house. considering that China is the second largest economy in the 
world, it is not surprising that when the economy in China declines, it will also have an impact on the global economy (Hafizah, 2020).

As explained above, this Coronavirus has almost spread to all countries, including Indonesia. Since the beginning of 2020 around the beginning of March, Indonesia began to be faced with a large epidemic that was haunting the health of the world's population (Ahmadan, 2020). At that time Indonesia must be ready to face this deadly virus, and must think about how to fight and resolve all the problems caused by the existence of Covid-19. Not only Indonesia, all countries affected by the Coronavirus also continue to look for various solutions. Indeed, it is so difficult to determine how a country should survive and eradicate every problem it faces. So it's not surprising, many countries have chosen an extreme decision by implementing a lockdown policy, and several massive policies that are solely to suppress the spread of the Covid-19 virus. It is different from Indonesia, where if we know that many countries have implemented a lockdown policy, but until now Indonesia has still chosen to implement this extreme policy. By implementing a lockdown policy, there will be many possible impacts, one of which is that the country's economic stability will be very influential. But in fact, even though Indonesia is without a lockdown policy, this epidemic still affects the country's economic stability.

Various efforts have been made by all countries to reduce and stop the spread of the Covid-19 virus. One of the ways in various countries, one of which is in Indonesia, is to carry out social distancing or physical distancing. This method is one of the many ways to prevent and control the spread of the Corona virus. Social distancing is a way of limiting someone from doing outdoor activities, avoiding crowded and crowded places and keeping a distance so as not to make direct contact with other individuals. In Indonesia itself, the application of social distancing is widely applied in various daily activities. For example, teaching and learning activities, work (work from home), meetings, seminars, and other events must be held at home or online. With this limitation of community activities, it will result in a decrease in overall economic activity, resulting in a decrease in the amount of production. Aggregate supply, or AS, refers to the total quantity of output-in other words, real GDP firms will produce and sell. The aggregate supply curve shows the total quantity of output real GDP that firms will produce and sell at each price level (Figure 1)
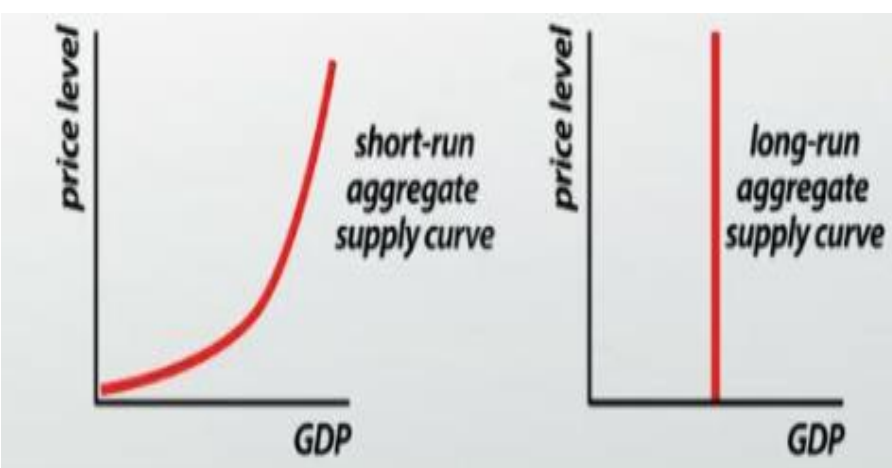

Figure 1. Aggregate Supply

Statistical analysis suggests a slow recovery due to a persistent effects of the supply shock, but surveys suggest a somewhat faster rebound with a recovery in 
aggregate supply leading the way (Bekaert, Engstrom \& Ermolov, 2020). When people are just staying at home, the consumption and expenditure activities of the community will also directly decline, or in other words the Aggregate Demand for the total production will end up continuing to decline (Hafizah, 2020).

As we already know, that from the beginning of 2020 the Indonesian economy has continued to decline, which is marked by many people who have lost their jobs due to layoffs, forced to close, or maybe go bankrupt because of the pandemic situation which is very difficult to find profit through trading activities, especially if the trading business is still relatively small. So it cannot be denied, there are many problems that must be resolved as a result of this disaster. Then how should Indonesia do in dealing with these problems? What solutions can promise to survive in the face of a disease that does not know when it will end? This question seems to arise clearly, given the quite alarming condition of the Indonesian economy.

By looking at the majority of Indonesia's population is Muslim and is the largest population in the world. So Muslims can certainly help and play a role in dealing with economic problems during this pandemic. As we know, that Islam always teaches its followers to always do good to others, such as orders to give zakat, give alms, give donations and so on. These orders are solely for the benefit of us indirectly. By carrying out these orders, it can eliminate the stingy, greedy, greedy nature that is readily in every human being, creates a high sense of humanity, and of course can also overcome all the problems that occur in life. So that with this great potential,

As a country with a Muslim majority, of course Islamic Social Finance (Zakat, Infaq, Alms, and also Waqf) has an important position as one of the solutions that can help the government in overcoming the social and economic problems of society during the pandemic. Of course, this Islamic social fund must be maximized to help every community need that is difficult or unable to fulfill on their own. The role of ZISWAF is very important and it is hoped that it can help restore the wheels of the economy, especially for the lower classes, although slowly but the results will definitely be good if this solution is carried out properly and optimally (Ahmadan, 2020). Then how is the condition of BMT in the midst of this many problematic conditions. Of course, BMT must have a strategy in order to continue under any conditions. The existence of BMT as an institution that manages and collects social funds such as the ZISWAF fund will affect solutions or efforts that can assist the government in dealing with the impact of this pandemic.

\section{THEORY AND METHODS}

The research method used in this paper is a qualitative method. Through this method, the authors interacted with the relationship between Islamic social finance and the Covid-19 pandemic problem. This method is inductive with the data used based on facts and phenomena that occur. This paper is a type of library research. What is meant by library research is the activity of collecting data with the aim of processing data based on reading sources and notes (Creswel, 2016). This paper uses secondary data sources from various literatures, generally from published journals and books. Data collection techniques used are collecting and processing data from secondary data sources. Because the data used is written data, the authors use 
citation techniques in data processing. Various sources in the form of journals and books, then imitating and changing them with various modifications. The data that has been collected are then analyzed to find the relationship between Islamic social finance and the Covid-19 problem. In addition to this purpose, this paper aims to increase the awareness of the Muslim community to carry out ZISWAF, especially zakat which is the obligation of Muslims.

\section{RESULTS AND DISCUSSION}

\subsection{Indonesia's Financial Condition during the Pandemic}

Indonesia is faced with many problems related to economic aspects as a result of Covid-19. The economy in Indonesia in 2020 is expected to grow negatively, unemployment and poverty rates will increase. Based on Year on Year calculations, economic growth in the first quarter of 2020 showed a weakening by only reaching $2.97 \%$ compared to the achievement of the first quarter of 2019 which was $5.07 \%$. Data in the second quarter was also less friendly, showing a deep decline of $-5.32 \%$, the worst since 1999. Data in the third quarter experienced a growth contraction of $3.49 \%$, while in the fourth quarter a growth contraction of $2.19 \%$. The impact of the declining percentage of the economy in Indonesia, one of which is the increase in unemployment and the poor population caused by layoffs during the Covid-19 pandemic (Official Statistics News, 2021).

The Covid-19 pandemic is something that has never been imagined by humans before. Earth seemed hit by such a big disaster. All humans are prohibited from doing activities outside the house. The whole world has been affected, and Indonesia is no exception. Various sectors are experiencing difficulties, including the economic sector. It is not only the workers who are experiencing economic hardship, but the producers or business owners are frantically thinking about their fate.

Because Covid-19 transmission can be through physical contact, all activities carried out outside the home are prohibited, such as direct buying and selling transactions, school, work, and even worship in public facilities were not permitted at the time when the corona virus was discovered which was the cause of the Coviddisease. 19. At that time, economic activity suddenly slowed down and continued to show a decreasing curve. Because the community does not want to be infected with the corona virus, consumers do not purchase goods, except for goods that can increase the body's immunity and can prevent the transmission of the corona virus. Such as vitamins, masks, hand sanitizers, disinfectants, etc. The producers are also confused, because unexpectedly the place where they are looking for money for their daily needs has become empty of buyers. Even, Producers and consumers have a close relationship in the economy. Where producers are the parties who provide jobs and also wages to their workers, in this case the workers are categorized as consumers. Meanwhile, consumers are parties who buy or pay an amount of value for goods or services provided by producers. So, if producers do not have consumers, and consumers do not work for producers, the economies of both parties are not going well.

As evidence that producers and consumers have a close relationship, it can be seen at the time of the Covid-19 pandemic. Due to the lockdown policy, which requires all people to stay at home or stay at home, there are no consumers who purchase products or services outside. Thus, producers lose their customers, which makes store or company finances significantly decrease, and even some business establishments have closed because they are unable to finance the company's 
expenses anymore. For business actors who still want to maintain their place of business, trying to reduce company burdens, one of which is by laying off employees. Because too few customers visit, too many employees are not required. Other than that, the cost of providing wages to employees can cover other business operations. Furthermore, consumers who experience dismissal or reduction in employees will try to be frugal by spending the remaining money or even using their savings only to buy daily necessities, such as food and buying groceries.

In the early era of the Covid-19 pandemic, GDP experienced a very significant decline due to reduced aggregate demand and aggregate supply. Indonesian economy by GDP (Product Gross Domestic Product) in Quarter II 2020 on the basis of current prices was IDR 3,687.7 trillion. But on the basis of constant prices with base year 2010 amounting to Rp2,589.6 trillion. When compared to on the basis of constant price or yoy (year on year), then growth economy in Q2 2020 experienced a contraction of $-5.32 \%$. If compared to Quarter I 2020, then the contraction is $-4.19 \%$. While the cumulative against First semester 2019, growth experienced a contraction of $-1.26 \%$, economic growth contraction Indonesia in Quarter II yoy deep enough. Based on the data, growth Indonesia's economy is experiencing negative growth on Second Quarter 2020. This article aims to assess the impact Covid-19 on growth economy and solutions (ekonomi.bisnis.com, 2020). One of them is to accelerate government spending or increase the budget allocation for social assistance and direct cash assistance. DPR with its supervisory function needs tourges the government to make policies that should be directed at encouraging the acceleration of national economic recovery (Wuryandani, 2020).

In a business cycle, this condition is called a recession. A recession is characterized by a decline in GDP, increasing unemployment and high inflation. The decline in aggregate demand is due to the lockdown policy in place in various regions and also the fear of not having a job, so that people start living frugally by spending their money on urgent needs only. And the demand for secondary goods is getting less, therefore the aggregate demand curve shifts to the left. It is also difficult for producers to bid on the products or services they sell because several business establishments have temporarily suspended their operations. Thus,

At that time, there was an issue circulating in the community that the government through Bank Indonesia would print large amounts of money. However, this policy idea is not a good thing for the Indonesian economy. In the short run aggregate supply, the central bank can reduce unemployment by increasing the money supply. However, the addition of money supply is not accompanied by normal running demand and supply, so inflation will soar. As said by the senior economist who was also the former Minister of Finance, Mr. Muhammad Chatib Basri, he said that if the rupiah was printed in large quantities, while only Indonesians who were in the country used it, while economic activity did not run because there was no production process, the risk of increased inflation would occur (Hamdani, 2020).

A part from the economy in the local sector experiencing turmoil. The international trade process had to be stopped. Due to social restrictions, all activities related to foreign countries are not allowed. Apart from the international trade process, namely export and import activities, traveling abroad or the entry of foreign tourists to Indonesia is also not allowed. All airlines are closed. This causes the producers of the export sector as well as the aviation and tourism sector to experience enormous losses. Because they have to keep paying for their employees, while they don't have customers coming. 
According to a statement delivered by the President of the Republic of Indonesia, Mr. Joko Widodo in the video that was broadcast on the YouTube account of the Presidential Secretariat, Indonesia must live in peace with Covid-19. He said that patients affected by Covid-19 could increase or decrease in an erratic way. This means that we must make peace with Covid-19 until an effective vaccine is found (Astuti, 2020).This indicates that the only way to deal with the corona virus is by vaccination. Even though Indonesia currently has the Covid-19 vaccine, not all Indonesians have received the vaccine. Elderly and civil servants who are priorities for vaccination.

However, we can prevent Covid-19 by implementing health protocols according to WHO recommendations, namely using a mask when you have to leave the house, washing your hands using antiseptic soap or using a hand sanitizer if running water is difficult to find, and keeping a distance of approximately 1 meter. This method is our effort to avoid the corona virus.

With this health protocol, we can start a new habit of life, known as a new normal. In mid-2020, Indonesia began to try to implement the new normal policy. Some offices that used to work from home or work from home have started working again from the office. Several business establishments that were previously closed or temporarily banned from operating have now begun to be allowed to carry out their business activities. Producers and consumers are starting to adapt to new life habits, by paying more attention to health and personal hygiene.

Likewise with the community economy. The economy began to adapt, began to experience improvement, although slowly. The process of buying and selling transactions immediately takes place again, the unemployed who have lost their jobs get jobs again, even though they are not in the same place. At least, this will be a green light for the Indonesian economy to revive. The curves for aggregate demand and aggregate supply are beginning to shift to the right. The demand for a good or service from consumers has started to increase. Manufacturers are increasingly active in offering their products or services with various strategies that are carried out. Starting from giving attractive promos to giving prizes in the form of bonuses.

Today many young people are starting to invest online through applications, and also many are trying out business opportunities by starting small businesses. They do this to fill their time at home and also seek additional income, and they are sure that the Indonesian economy will revive so that it can benefit them. This is a positive trend for the Indonesian economy. With the Indonesian economy running again, policies in the context of poverty alleviation and community equality can be immediately re-implemented.

\subsection{Islamic Social Finance Concept}

In Islamic economics, there are two main focuses of the economy. Namely, Islamic commercial finance and Islamic social finance. In Islamic commercial finance, the goal is to generate profit or be profit oriented, while in Islamic social finance the goal is to help fellow Muslims and get rewarded. The term Islamic social finance first appeared by IRTI-IDB with the intention that the role of Islamic finance can be stronger and can reach all people (Cupian, 2020). Especially some groups categorized as the lowest class of society, who cannot use Bank facilities, because they do not meet the requirements to become Bank customers and borrow money from the Bank. The benefits of Islamic social finance are besides the purpose of helping and seeking Allah's pleasure, namely to strengthen the social side of non-micro Islamic financial 
institutions, such as Islamic banks and Islamic insurance. And to strengthen and develop the Islamic social economy sector itself. As well as fostering a simultaneous and complementary relationship between zakat, infaq, sadaqah and waqf institutions with Islamic microfinance institutions so that the objectives of these institutions can be obtained more effectively and efficiently (Cupian, 2020).

Islamic social finance instruments have alleviated poverty and improved the socio-economy for more than 1,400 years. In fact, these Islamic social activities are carried out in countries that are not Islamic countries, such as Singapore and England, because the benefits of Islamic social finance are not only about religiosity or religious belief, but economically the benefits are very large. Usually, Islamic social finance instruments are used for education and health development, infrastructure development and poverty alleviation through reducing social inequality in society (Cupian, 2020).

The economy fluctuates, meaning that the economy can be high but it can also be low or go into a recession. The government has made efforts to prevent a recession through monetary policy. However, the government and Bank Indonesia certainly cannot work alone, so the synergy of Islamic financial institutions is needed to realize a recession-free Indonesia. This can be achieved through activities of providing assistance to the community, so that the wheels of the economy continue to run in the presence of supply and demand. The Islamic social finance institution that plays a role in doing this is the ZISWAF institution. And also Islamic microfinance institutions such as BMT can help realize the ideals of the Indonesian economy.

Zakat, infaq, and alms institutions provide assistance to meet daily needs, such as for food and for school needs. Waqf institutions as a means to create productive places, such as mosques and Islamic boarding schools. In addition, cash waqf has begun to be found. With the main focus of this assistance is to reduce social inequality. BMT can help lower-income people who do not have access to lending and borrowing at the bank to provide initial capital to open a business. And also provide qardul hasan assistance or voluntary loans. This means that people who do not have collateral as proof of their ability to pay debts can borrow a certain amount of money without needing to be returned. Of course, this is subject to strict supervision, so that the borrowers of the money do not use it for non-urgent matters.

Based on data held by Baznas, the potential for zakat in 2019 in Indonesia will reach around $\mathrm{Rp}$. 2333.6 trillion which comes from zakat on agriculture, zakat for money, zakat on animal husbandry, zakat for companies, and zakat for income.(Cupian, SE., Nd)However, in reality the zakat collected in 2019 is Rp. 9.6 tirilun, less than half of the existing potential. This indicates that there are still many Indonesian Muslims who do not pay zakat, or around Rp. 224 trillion. This is certainly a big homework for the government and the amil zakat institution itself.

Although in terms of zakat there is still little public awareness to pay it, in terms of infaq and sadaqah it is quite large in application. The World Giving Index says that Indonesia is one of the most generous countries in making donations in cash (Cupian, 2020). The World Giving Index (WGI) is an annual report published by the Charities Aid Foundation, using data collected by Gallup, and ranking more than 140 countries around the world based on how generous they are in donating. In the WGI 2021 report, Indonesia ranks in the top 2 out of 3 categories or indicators that become WGI's measurement, namely donating to foreigners/unknown, donating money and volunteering/volunteer activities. The results of CAF's research show that more than 8 (eight) out of 10 Indonesians donated money this year, while the level of 
volunteerism in Indonesia is three times higher than the world average (Charities Aid Foundation, 2021). It can be seen that at the time of the Covid-19 disaster, Indonesians flocked to open online donations for Covid-19 patients, doctors and nurses, as well as people whose economies were severely affected.

With the majority of Indonesia's population being Muslim, which is $88 \%$ of the total population of Indonesia, the poor should have their economy covered. This means that there is no longer social inequality. Poor people who previously received zakat assistance (mustahik) turn into zakat distributors (muzaki) if zakat payments are made optimally. The economic class of Indonesian society is in the middle to above level.

As a result of technological sophistication, now the Indonesian Muslim community can make zakat, infaq and sadaqah payments at their respective homes via gadgets, this greatly facilitates zakat distribution, especially during a pandemic like this time. With the existence of fintech innovation, it can provide many conveniences, one of which is in terms of efficiency and transparency (Cupian, 2020).The costs incurred by the distributors of zakat are very small. They do not need to go directly to the location of the zakat collection institution which requires transportation and food costs. However, they only need the cost to buy the internet, in terms of time it also doesn't take long, only a few minutes they can save their wealth. In terms of transparency, reports on parties who receive zakat funds can be displayed on the fintech page, or can send electronic mail (email) directly to the channeling party. This can also be a positive thing that can increase public trust in the institution, so that it will return to zakat on this institution.

Islamic social finance instruments, strongly support the SDGs system or sustainable development. Most of the 17 developmental goals of the SDGs comfortably match with the long-term objectives of shariah and there is good scope for the stakeholders of awqaf to develop waqf-based development plan in line with the framework of SDGs. Additionally, it finds that the global awqaf enjoy sufficient financial capacity to help muslim majority countries to realise some of the most relevant and urgent maqasid-oriented SDGs in a timely manner (Abdullah, 2018).

Through zakat, donations and sadaqah can empower productivity and for consumptive activities. The empowerment stage includes assessment, capacity building, zakat distribution, and assistance. ZIS funds disbursed for productive activities can support the SDGs system, namely eliminating poverty and reducing inequality by utilizing zakat assistance to open productive businesses. Meanwhile, ZIS funds used for consumptive activities can eliminate hunger in Indonesians. Through waqf, both land and cash waqf can improve social facilities and provide investment and business business, with the aim of sustainable development in the form of good health and quality education. From investment and business, it can generate profits that can be used as further venture capital or to meet daily needs. The purpose of all this is to reduce the gap and change the status of the recipient of zakat (mustahik) to giver of zakat (muzakki) (Cupian, 2020).

The purpose of implementing sharia economics in Indonesia is to become a country with the largest Islamic financial system in the world, both Islamic commercial finance and Islamic social finance. Therefore, to realize the ideals of the nation, it is necessary to have cooperation from the community. Not only the government is responsible for making it happen, but the people must also support it. Starting from the application of Islamic commercial finance, such as the use of Islamic banks, until finally it is applied to Islamic social matters. 


\subsection{Zakat, Infaq, Alms, and Endowments (ZISWAF)}

Islamic social fund is proliferating in this most populous Muslim country, particularly in the time of this pandemic. During early 2020, there was a substantial growth of the collection of Islamic social funds for nearly $70 \%$ compared to the last year's figure, which is mainly driven by the digitalization of social fund payment. Religiosity, trust, and perceived behavioral control have a positive and significant effect on the intention to donate through online platforms. Furthermore, when it comes to a specific categorized SDG program, the people sector is the highest priority, followed by prosperity and peace sectors (Yunice, Intan, Faaza, 2021).

ZISWAF stands for Zakat, Infaq, Alms, and Waqf. ZISWAF can be used as an alternative solution to solve problems such as poverty and unequal income distribution if ZISWAF management can be managed optimally. ZISWAF is the embodiment of Islamic philanthropy. According to Ilchman (2006), the meaning of Islamic Philanthropy is a form of caring for fellow human beings which is aimed at giving charity to others in need (Sardiana \& Zulfison, 2018).

Zakat is one of the commands from Allah SWT which is included in the pillars of Islam and must be carried out by all Muslims. Why does Allah SWT oblige us as Muslims to give zakat? Because in the view of Islam, the universe and everything in it belongs to Allah absolutely. So that humans who are on this earth, are only given the power to manage it. Thus, as people who are given power, we should obey and carry out what the owner of the universe wants. One of the things we have to do as humans who manage the universe and everything in it is to pay zakat. Zakat here can be interpreted as the transfer of property ownership from the rich to the poor, because in every wealth they have, other people's rights are tucked away.

As previously mentioned, the condition for assets or assets that must be paid for zakat is that they have reached the nishab and haul. In addition, of course, these assets must be fully owned by the owner, obtained in a lawful way, for example from inheritance or purchase. These assets can also grow or increase if they have the potential to develop. When we do zakat, it must be ensured that the assets we have have exceeded our basic needs or the fulfillment of our daily needs. And lastly, of course, our assets must be free from debt because if they are still related to debt, these assets are free from zakat or not obliged to pay zakat.

Zakat is divided into two types, the first is zakat nafs or soul. This zakat can also be referred to as zakat fitrah which is synonymous with the holy month of Ramadan, because this zakat is indeed issued after completing the fasting of Ramadan. Zakat Fitrah is obligatory for every Muslim, whether male or female, adult or small, free or slave. The amount of zakat that must be paid is 3.5 liters or 2.5 kilograms of staple food in the area concerned. For example in Indonesia, the staple food is rice, meaning that the zakat that must be paid is 2.5 kilograms of rice. Zakat fitrah is issued to purify a fasting person from bad deeds and words and to help and feed the poor.

In addition to zakat fitrah or zakat nafs, there is also what is called zakat maal or zakat on assets. The assets here include, among others, gold, silver, commercial products, seeds, fruits, and zakat from livestock. In essence, assets include products from commerce, agriculture, trade, marine products, livestock products, treasures, gold and silver and so on. Maal according to the conditions can be interpreted as anything that can be owned or controlled and can be used as usual. So, the conditions that must be met so that something can be said to be maal is that it can be owned and can be used or the benefits of something that are considered maal can be felt. Thus, what is required in zakat maal cannot be applied to zakat fitrah. 
In the Koran, with regard to zakat, almsgiving, hadyu, grants, jizyah, and waqf, all of them are included in Infak. So in essence, this Infak is related to the giving or spending which is prescribed by religion only, such as the obligation to pay zakat and the advice of the sunnah such as waqf and alms.(Fitra Rizal, 2021). If we compare the difference between alms and donations, it is clearly different. In general, almsgiving has a stronger meaning in terms of the object of giving, which can be either material or non-material. We can find non-material here in everyday life such as actions to help, smiling, and so on. When it comes to coverage, Infak is broader in scope compared to sadaqah. Where it has been explained previously, that zakat, zhadaqah, waqf are included in the scope of infak. In addition, in relation to the target recipients of donations and alms, it turns out that it is also different. Alms can be given to other than humans, for example animals or plants, while infaq can only be given to humans.

Waqf is also an extraordinary practice, which includes the practice of almsgiving, the reward of which will not be cut off as long as the benefits are still being felt. After someone has done waqf, hopefully it can make them more sincere in giving their property to be used by others, and can teach about how we as humans should not love and be too proud of the assets we have, because all of them are entrusted. Most people probably only know that waqf is related to places of worship, but apart from that there are still a lot of assets that can be used as the object of waqf. For example, such as springs, roads, and places where the community at large can benefit from it. Of course, of all the assets that are used as objects, it must be fully owned, but later when the assets have been donated, the name of the ownership will be collectively, not in his personal name anymore. That way, it is not permissible for someone who wants to fully control or manage according to his own will, unless that person has been given the mandate to manage it.

\subsection{Factors that affect the level of public awareness to pay zakat}

In terms of paying zakat, there are several factors that can affect the level of public awareness to implement it, namely as follows:

1. Religiosity Factor, it means not only from people's knowledge which shows the level of religiosity, but also with the level of understanding and experience of the community regarding religious teachings. A high level of religiosity indicates that people are motivated to pay Zakat, donations and alms. This factor is a condition caused by a person's behavior with the background of the attitude of the community in responding to God's orders in order to get good both in this world and in the hereafter. The respondent or the community knows and understands their obligation to pay ZIS, which ZIS should be submitted to the Amil Zakat Institution, where the institution will later distribute ZIS funds to parties in need or what is called mustahik (Syafiq, 2018).

2. Psychological Factors,meaning that people will take an action because of psychological factors which are encouragement from themselves without coercion from others. Likewise, paying zakat, infaq and alms, where the person who does this is a person who tends to have confidence, understanding, and a positive attitude. In this case, paying Zakat, Infaq, Alms (ZIS) to the Amil Zakat Institution (LAZ) is a positive action because it has an impact on both oneself and others who receive it.

3. Social Factors, paying Zakat, infaq, alms is religious advice that is not only from family and / or reference groups invitations. People will be moved to do 
these practices if there is belief and understanding that is accompanied by an intention in themselves and not being forced by others. Therefore, just an invitation from family and / or social groups will not significantly affect a person's motivation to practice this because basically Zakat, Infaq, Alms (ZIS) worship is a teaching taught by Islam (Syafiq, 2018).

4. Government Regulation Factors, Most people practice ZIS on their own accord or encouragement. This is because regulations related to the management of Zakat, Infaq, Alms (ZIS) have not been maximally socialized. There are still many people who think that ZIS is a space of privacy between humans and their God and the procedure or process has been regulated by itself. Then, people only voluntarily pay ZIS to the Amil Zakat Institution, but if it is not for their own will, they will not pay ZIS to the Amil Zakat Institution.

5. Attribute Factors of Zakat Institutions,zakat institution plays an important role in the collection and management of zakat. Where is the ability of the Amil Zakat institution to motivate people to pay ZIS to LAZ. The ZIS management will have a positive impact and the community will feel satisfied if the ZIS is managed by LAZ in a transparent and accountable manner. In addition, professionalism is also needed in its management, so that later it can increase community motivation to pay ZIS to LAZ. If these conditions are not met, it can create a negative impression and the community is dissatisfied with the management carried out by LAZ.

\subsection{The existence of BMT in the face of the Covid-19 pandemic}

Considering that Indonesia is a country where the majority of the population is Muslim, this could be a huge potential for Indonesia. This great potential, if optimized properly, can be used as an additional solution or alternative in dealing with a pandemic and can continue to survive, and of course this can help the government too. With the majority of Indonesia's population, social funds will have a great opportunity. Of course, in managing social funds such as zakat, infaq, alms (ZIS) funds, an institution must be able to manage them. Then, the existence of this BMT is expected to be able to encourage businesses that lack capital, and of course be able to help the government in solving all existing problems.

BMT is a microfinance institution that consists of 2 institutions, each of which has a different function, namely, baitul maal and baitul tamwil. Baitul Maal itself is a financial institution whose activities are to accept social funds, such as zakat, infaq, alms, then try to optimize the distribution of these funds in accordance with the rules and mandates. Baitul Maal has actually been implemented and has existed since the time of the prophet Muhammad SAW. At that time this institution also functioned as a storage area. So, if you look at what the Apostle did, such as the income and expenditure process, if you see it now, it is a form of what is called welfare oriented. After the Baitul Maal Institution existed, the funds that came from both people came from social funds, such as donations and alms, or also from the funds that must be issued such as zakat will be collected in this institution, then it will be distributed back based on the interests of the people. Baitul Tamwil is a financial institution whose activities are to carry out productive business development and investment to improve the economic quality of micro and small entrepreneurs, for example by inviting and encouraging them to regularly save and support financing economic activities. So that the collection of funds from the Baitul Tamwil comes from third 
party deposit funds, while the distribution of financing can be in the form of investments or other financing carried out based on sharia principles. Baitul Tamwil is a financial institution whose activities are to carry out productive business development and investment to improve the economic quality of micro and small entrepreneurs, for example by inviting and encouraging them to regularly save and support financing economic activities. So that the collection of funds from Baitul Tamwil comes from deposits of third parties, while the distribution of funds can be in the form of investment or other financing carried out based on sharia principles. Baitul Tamwil is a financial institution whose activities are to carry out productive business development and investment to improve the economic quality of micro and small entrepreneurs, for example by inviting and encouraging them to regularly save and support financing economic activities. So that the collection of funds from baitul tamwil comes from deposits of third parties, while the distribution of funds can be in the form of investment or other financing carried out based on sharia principles (Ahmadan, 2020).

It has been almost 2 years that Indonesia and other countries in the world are still busy dealing with the Covid-19 outbreak. Bank Indonesia said as many as 87.5 percent of MSMEs were affected by the Covid-19 pandemic. Of this number, around 93.2 percent of them were negatively affected on the sales side (bisnis.com, 2020).

Within a few weeks, perhaps even days, there will be massive social, economic and political impacts throughout the world. If we focus on the grassroots level, micro, small and medium enterprises (MSMEs) are the biggest hit (Central Bureau of Statistics, 2018).

It is undeniable that MSMEs are the dominant sector in Indonesia's economic structure. There are 64 million MSME units absorbing 117 million workers or equivalent to 94 percent of the total workforce (BPS, 2018)There are so many impacts caused by this virus, both from an economic, social, political, educational, and so on. This impact is also felt by sharia microfinance institutions, namely Baitul Maal Wat Tamwil, which is an institution with the legal entity of a sharia savings and loan cooperative. This institution provides services to the lower middle class society, which aims to provide assistance to meet the basic needs needed by the community and to develop the businesses they are running. Because Micro, Small and Medium Enterprises are the main target service for BMTs, in a pandemic situation like this, MSMEs have a big impact which can also affect BMT itself. In addition, according to what President Joko Widodo said in his speech, another consequence of this pandemic the government took action to ease credit for the community for people affected by the pandemic, so that this was used as an opportunity for BMT members who even though they had good cash flow but wanted to postpone the installment payment. On the other hand, due to choking to make ends meet during the pandemic, many of the BMT members withdrew their funds so this is used as an opportunity for BMT members who, despite having good cash flow, want to postpone their installment payments. On the other hand, due to choking to make ends meet during the pandemic, many of the BMT members withdrew their funds so this is used as an opportunity for BMT members who, despite having good cash flow, want to postpone their installment payments. On the other hand, due to choking to make ends meet during the pandemic, many of the BMT members withdrew their funds (Hakim et al., 2021).

Even though the impact of this pandemic has created quite a severe crisis, every institution, including Islamic microfinance institutions, must be able to maintain its 
existence and function in helping and serving the community, and working to alleviate poverty. So that BMT must be able to analyze the risks of the Covid-19 pandemic, look for new alternatives and conduct in-depth studies to be able to maintain the existence of BMT in the community.

Thus, the Baitul Maal wat Tamwil financial institution is a microfinance institution that is an alternative to alleviate problems related to helping people with weak economies. So, this BMT is operated on the basis of the principle of profit sharing, helping micro and small entrepreneurs. So now it is clear that BMT not only provides services, be it savings or financing for micro and small businesses that need capital, but also supports the fulfillment of the needs of people who are in a weak economic situation.

Thus, the existence of BMTs can provide assistance to entrepreneurs affected by the pandemic in the form of business capital. In addition, funding assistance for Micro, Small and Medium Enterprises that are still surviving and struggling in a pandemic crisis like this. Because when the capital is available, it will be easier to maintain the business. With the existence of MSMEs that are more prone to shaking or not easy to survive in pandemic conditions, and also easily fall into the abyss of bankruptcy, it is no wonder that the provision of capital funds from BMT is very influential and can reduce the impact of the existence of Covid-19. To strengthen it again, if MSMEs are in a crisis position and many have gone bankrupt, it will directly impact on declining economic growth.

\subsection{Solutions to Overcome Indonesia's Economic Problems During the Covid-19 Pandemic}

There are solutions offered in the context of the concept of Islamic social finance and economics to overcome economic problems in Indonesia, including the following:

1. Distribution of direct cash assistance that comes from zakat collection units or from people who have more income, where the assistance is in the form of zakat, infaq, or alms. This needs to be emphasized to people who have more income that can be distributed to the poor, especially at this time, it is more focused on the poor who are affected by Covid-19. Assistance in the form of zakat, donations and alms is a scheme of Islamic economic philanthropy, which has the potential to improve or improve the Indonesian economy (Iskandar, Possumah, \& Aqbar, 2020). However, this assistance has not yet reached the expected target to be distributed to people who need it to the maximum. Therefore, efforts are needed to overcome this, namely:

a) Establish a baitul mall center by making a mosque in the community as the center for the surrounding community and under the coordination of the Zakat Management Organization (OPZ) must be registered as a Zakat Collecting Unit or abbreviated as UPZ. In this case, zakat payments can be made online due to the covid-19 pandemic conditions which have resulted in mosques in the community unable to function temporarily.

b) Establishment of Zakat Centers in mosques and on-campus dictionaries as a form of strengthening literacy related to the calculation of zakat.

c) nationally and on a large scale solidarity fund movement led directly by the President of the Republic of Indonesia with the support of official government media and the public.

2. Increasing waqf with cash waqf schemes, productive waqf or waqf linked sukuk waqf in order to strengthen waqf. The need for cooperation between the 
Indonesian Waqf Board (BWI) and the Sharia Financial Institution (LKS) which aims to promote this scheme which can eventually be used for the development of various waqf-based infrastructure. In this case, good and professional waqf management is needed so that existing waqf can be used productively, sustainably, and of course optimally. Because if it is not managed properly, the waqf cannot be used optimally. If we look at its development to date, waqf can be in any form that has economic value, such as patents as productive waqf. When a vaccine for Covid-19 was discovered, hopes to donate his patent so that it can be used by all people in the world. Therefore, it is very necessary to promote waqf to the community, including vaccine inventors during the Covid-19 pandemic (Iskandar et al., 2020).

From what we know, waqf has a very important role in infrastructure development such as various public facilities and economic empowerment of the people, where waqf is another way needed to deal with the problem of poverty in society, especially for people affected by Covid-19, the community. contribute actively, especially for people who are classified as rich and able to help alleviate the burden of the poor. In Indonesia, which is a country that has a Muslim majority population, efforts to collect and manage cash waqf should be appreciated by the Muslim community in Indonesia at least culturally, as in the current pandemic situation in particular.

3. There is assistance in the form of business capital in times of crisis, where many MSMEs find it difficult to survive so that their businesses can continue to operate during a crisis. The problem that makes it difficult for MSMEs to survive is that they have limited capital to run their businesses. The UMKM group is not a muzakki party, but when the group experiences a crisis it can make it a poor community which eventually becomes a mustahik party, in other words it can increase the number of mustahik and besides that the number of muzakki continues to decline. Therefore, there is a need for capital assistance for the MSME group, where the provision of capital can be done by, for example, providing additional stimulation of sharia banking relaxation and restructuring or deferral of sharia credit / financing payments for the next few months (Iskandar et al., 2020).

4. The provision of business capital above can also be followed by a qardhul hasan loan. In sharia economic / financial terminology, qardhul hasan is a loan provided without any additional benefits or benefits but it needs to be emphasized to repay it. Qardhul hasan is a product of the Islamic financial system, which is a product that has the potential to improve or enhance the economy. There are several distributions that can be selected to be carried out, namely through Sharia Microfinance Institutions (LKMS) in financing nano businesses, where the funds can come from the public, private companies, or from BUMN / BUMD. Then, This can be done through direct loans without a margin for business or consumption provided by companies, whether private or BUMN / BUMD, for employees or partners, where CSR funds or other posts are a source of funds in this loan. In addition, you can also go through Baitul Mal wa Tamwil (BMT). According to Rianto (2015), BMT is a microfinance institution that uses the concept of profit sharing, advances micro-business with the aim of elevating the degree and dignity and supporting the interests of the poor and needy (Ahmad \& Harahap, 2020). BMT is one of the institutions that functions to solve economic problems by implementing 
empowerment activities through qardhul hasan products. The application of this product is not only for financing, but also equipped with a mentoring model that can make the implementation of financing run well.

5. In order to strengthen MSME businesses that are experiencing crisis, some of the funds for business capital are collected by OPZ in addition to funds obtained from the banking sector and qardhul hasan. Helping MSME groups who are facing crisis conditions due to the impact of Covid-19, which can be included as the asnaf (zakat recipient) group, namely groups of the poor, fii sabilillah, and gharimin (Iskandar et al., 2020).

6. Providing an understanding of sharia economics and finance to the public which aims to increase public literacy regarding sharia economics and finance. This can be channeled by providing educational assistance to people affected by Covid-19; granting permits and facilities to carry out Distance Program (PJJ) activities for public or private universities, where the program provides sharia economic programs, one of which is emphasized as fostering attitude or morals; as well as the development of internet network infrastructure to support PJJ for free, which is spread evenly throughout Indonesia.

In order to smoothen liquidity of sharia online players, it is necessary to develop Islamic financial technology, which also focuses simultaneously on increasing social finance (ZISWAF) in addition to commercial finance. Likewise in this case, namely developing market finance so that the accumulation of traditional markets and SMEs with a total of up to 60 million until now, this is aimed at meeting demand and supply at home or abroad, especially in this lockdown situation (Iskandar et al., 2020).

\section{CONCLUSION}

Indonesia has so far experienced economic problems, especially exacerbated by the Covid-19 outbreak which has made Indonesia's economic level decline. This is indicated by the increasing poverty rate, many entrepreneurs going bankrupt due to lack of capital to run their businesses. The problems that arise are of course there are solutions to overcome them, with the role of Islamic social finance through ZISWAF and BMT to overcome these problems. ZISWAF (Zakat, Infaq, Almsgiving, and Endowments) is an alternative solution to overcome problems such as poverty, unequal income distribution if ZISWAF management can be managed optimally. Zakat is an obligation of Muslims, where the zakat is given to those who need it or it is usually called mustahik. Zakat is an activity of giving assets that we have on condition that they have reached the haul and nishab. Zakat is divided into two types, namely zakat nafs or life and zakat maal or zakat on assets. The zakat of the nafs or soul can also be referred to as zakat fitrah which must be fulfilled in the month of Ramadan. Zakat maal or zakat on assets, where the assets here include gold, silver, trade products, seeds, fruits, and zakat on livestock. Maal according to the conditions can be interpreted as anything that can be owned or controlled and can be used as usual. So, the conditions that must be met so that something can be said to be maal is that it can be owned and can be used or the benefits of something that are considered maal can be felt. Infaq is an activity of giving assets in the form of assets or other things to other people in need in accordance with what religion dictates, such as faqir, poor, orphans, relatives, and others. Almsgiving is everything someone gives to another person who is done voluntarily, which aims to expect the reward and pleasure of Allah SWT. Waqf is a transfer of ownership of property that stops from its ownership, 
where the assets are given in the presence of benefits that can be enjoyed or felt by the general public and can last a long time solely for seeking the pleasure of Allah SWT Almsgiving is everything someone gives to another person who is done voluntarily, which aims to expect the reward and pleasure of Allah SWT. Waqf is a transfer of ownership of property that stops from its ownership, where the assets are given in the presence of benefits that can be enjoyed or felt by the community in general and can last a long time solely for seeking the pleasure of Allah SWT. Almsgiving is everything someone gives to another person who is done voluntarily, which aims to expect the reward and pleasure of Allah SWT. Waqf is a transfer of ownership of property that stops from its ownership, where the assets are given in the presence of benefits that can be enjoyed or felt by the community in general and can last a long time solely for seeking the pleasure of Allah SWT.

There are several factors that influence the level of public awareness in paying zakat, namely: (1) the factor of religiosity; (2) psychological factors; (3) Social factors; (4) Government regulatory factors; (5) Zakat attribute factors. The existence of BMT (Baitul Maal wat Tamwil) can also play an important role in overcoming Indonesia's economic problems such as those that were caused during the Covid-19 pandemic. BMT is a microfinance institution that implements a profit-sharing system, advances micro-business so that it can raise the status and dignity and support the interests of the poor and needy people. BMT is a microfinance institution that consists of 2 institutions, each of which has a different function, namely, baitul maal and baitul tamwil. This institution provides services to the lower middle class society, which aims to provide assistance to meet the basic needs needed by the community as well as business capital to develop the businesses they are running.

There are solutions offered in the context of the concept of Islamic social finance and economy to overcome economic problems in Indonesia such as the problems experienced during the Covid-19 pandemic, including the following; (1) The distribution of BLT originating from zakat collection units or from people with more income, assistance in the form of zakat, infaq, or alms; (2) Increasing waqf with cash waqf schemes, productive waqf or waqf linked sukuk waqf in order to strengthen waqf; (3) Assistance in the form of business capital to Micro, Small and Medium Enterprises (UMKM) groups experiencing crisis conditions; (4) Providing venture capital followed by a qardhul hasan loan scheme; (5) Providing understanding to increase literacy related to sharia economics and finance; (6) Sharia financial technology development. 


\section{REFERENCE}

Abdullah, Mohammad (2018). Waqf, Sustainable Development Goals (SDGs) and Maqasid Al-Shariah, International Journal of Social Economics, Volume 45 Issue 1 Ahmad, S., \& Harahap, R. (2020). The Role of Baitul Mal Wa Tamwil (Bmt) in Community Economic Development. Human Falah, 7 (1), 19-29.

Ahmadan, D. (2020). Islamic Social Finance in Facing the Plague of Covid-19. La Riba, 1(02), 1-15. Iskandar, A., Possumah, BT, \& Aqbar, K. (2020). The Role of Islamic Social Economics and Finance during the Covid-19 Pandemic. SALAM: Journal of Social and Cultural Affairs Syar-I, 7 (7), 625-638. https://doi.org/10.15408/sjsbs.v7i7.15544

Astuti, NAR (2020). Jokowi: We Must Live in Peace with Covid-19 until a Vaccine Is Found. In Kompas.com.

Bekaert, Geert, Eric Engstrom, and Andrey Ermolov (2020). "Aggregate Demand and Aggregate Supply Effects of COVID-19: A Real-time Analysis," Finance and Economics Discussion Series 2020-049. Washington: Board of Governors of the Federal Reserve System, https://doi.org/10.17016/FEDS.2020.049Cupian, SE., MP. (2020). Ziswaf Institution Empowerment.

Berita Resmi Statistik (2021). Kondisi Perekonomian Indonesia di Tengah Pandemi Covid-19, http://bem.fmipa.unej.ac.id/kastrad-beraksi2-kondisi-perekonomianindonesia-di-tengah-pandemi-covid-19/

Bisnis.com (2020). Survei BI : 87,5 Persen UMKM Indonesia Terdampak Pandemi Covid19, https://ekonomi.bisnis.com/read/20210319/9/1370022/survei-bi-875-persenumkm-indonesia-terdampak-pandemi-covid-19

Charities Aid Foundation (2021). Indonesia Kembali Jadi Negara Paling Dermawan di Dunia, https://filantropi.or.id/indonesia-kembali-jadi-negara-paling-dermawandi-dunia/

Creswell W. John. (2013). Research Design Pendekatan Kualitatif, Kuantitatif, dan Mixed. Yogyakarta : Pustaka Pelajar.

Euis Amalia and Indra Rahmatullah (2020). Strategic Alliances between Sharia Microfinance Institutions and Financial Technology in Strengthening Small Micro Enterprises (MSEs)

Duarte, F. (2019). How much time Indonesians spend on social media.

Fitra Rizal, HM (2021). Islamic Philantropy a Solution to Poverty Problems Due to the Covid-19 Pandemic. Al-Manhaj, 3 (1), 35-66.

Hafizah, GD (2020). Sharia Economic and Financial Role in the Covid-19 Pandemic Time. Liquid, 1, 55-64.

Hakim, L., Brilyanda, A., Aureli, P., Adam, Z., \& Sagita, IA (2021). BMT Sustainability Analysis in the Covid 19 Pandemy Based on Business Models and Selective Funding Member Services (Selective Lending). 01 (01).

Hamdani, T. (2020). DPR Suggests BI to Print Rp. 600 T of Money, Former Minister of Finance Reminds the Risk.

Jumlah Usaha Mikro Kecil dan Menengah (UMKM), Badan Pusat Statistik (2018).

PDB Indonesia 'Hard Landing', Pertumbuhan Ekonomi Kuartal Kedua 2020 Minus 5,32 Persen", 5 Agustus 2020, https://ekonomi.bisnis.com/ Read/20200805/9/1275221/ Pdb-Indonesia-Hard-LandingPertumbuhanEkonomiKuartal-Kedua-2020-Minus532-Persen, diakses 5 Agustus 2020

Sardiana, A., \& Zulfison. (2018). Implementation of Islamic Financial Literacy in Community Ziswaf Fund Allocation. Maqdis: Journal of Islamic Economic Studies, 
3 (2), 171-180.

Sumarni, Y. (2020). The Covid-19 Pandemic: Economic and Business Challenges. AlIntaj, 2, 46-58.

Syafiq, A. (2018). Increasing Public Awareness in Carrying Out Zakar, Infaq, Alms and Waqf. Ziswaf, Journal of Zakat and Waqf, 5(2), 24.

Virus Corona https://www.alodokter.com/virus-corona Wuryandani (2020). Dampak Pandemi Covid-19 terhadap Pertumbuhan Ekonomi Indonesia 2020 dan Solusinya, Vol. XII, No. 15/I/Puslit/Agustus/2020

Yunice, Intan, Faaza (2021). How Islamic Social Funds Support Sustainable Development Goals During Covid Outbreak? The Role of Religiosity, Trust, and Perceived Behavioral Control, Jurnal Ekonomi dan Keuangan Islam, Vol. 10, No. 1, 2021; pp. 84-103, ISSN: $2089-6239$ (P); 2549-0648 (E), DOI: 10.22373/share.v10i1.9302 